\title{
Cupping at the ends of ribs is not always rickets
}

\author{
Ankur Kumar Jindal, ${ }^{1}$ Amit Rawat ${ }^{2}$
}

${ }^{1}$ Department of Pediatrics, Post Graduate Institute of Medical Education and Research, Chandigarh, India ${ }^{2}$ Pediatric Allergy and Immunology Unit, Post Graduate Institute of Medical Education and Research, Chandigarh, India

\section{Correspondence to}

Dr Amit Rawat, rawatamit@ yahoo.com

Accepted 12 June 2017

\section{DESCRIPTION}

A 7-week-old baby boy presented with a history of cough, loose stools and respiratory distress since last 7 days. At admission he had a respiratory rate of $64 / \mathrm{min}$, a heart rate of $144 / \mathrm{min}$ and an oxygen saturation of $56 \%$. Chest examination revealed crepitations in both lung fields. Rest of the examination was unremarkable. Investigations revealed haemoglobin $82 \mathrm{~g} / \mathrm{L}$; white cell count $11.2 \times 10^{9} / \mathrm{L}$ (differential counts: polymorphs 68\%, lymphocytes $1 \%$, monocytes $26 \%$ and eosinophils $5 \%$ ); absolute lymphocyte count $0.11 \times 10^{9} / \mathrm{L}$; platelet count $102 \times 10^{9} / \mathrm{L}$ and $\mathrm{C}$ reactive protein $239 \mathrm{~g} / \mathrm{L}$. Chest $\mathrm{X}$-ray showed non-homogenous opacities in bilateral lung fields (more on right side) with an absent thymic shadow, cupping at the anterior end of ribs

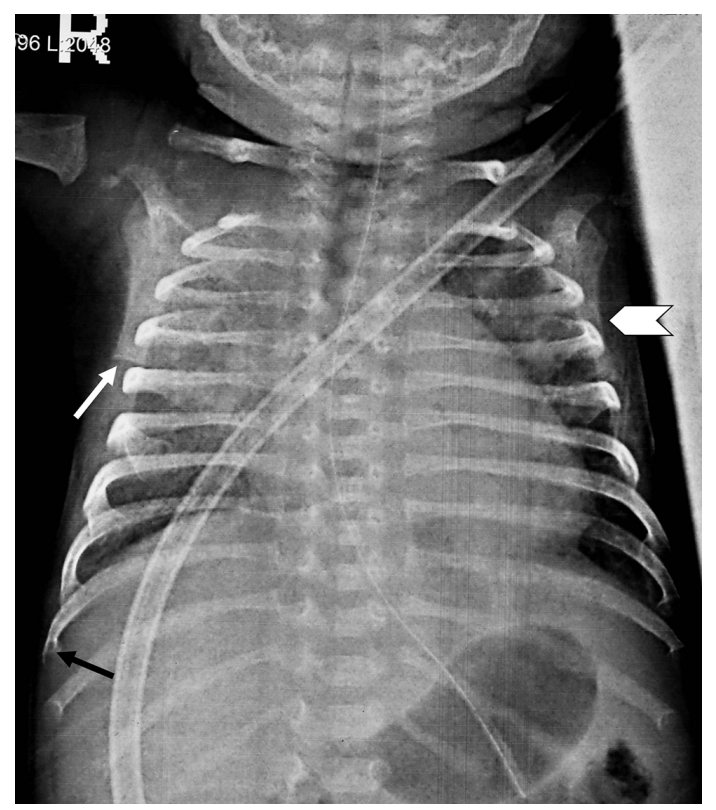

To cite: Jindal $A K$, Rawat $A$ BMJ Case Rep Published Online First: [please include Day Month Year]. doi:10.1136/bcr-2017220642

\section{CrossMark}

Figure 1 Cupping at the anterior end of ribs (black arrow), flattening of the lower end of the right scapula (white arrow) and a spur at the inferior-lateral angle of the left scapula (white arrow head).

\section{Learning points}

- Severe combined immunodeficiency (SCID) is the most severe form of primary immunodeficiency disorder.

- All paediatricians and neonatologists must be aware of the radiological changes of adenosine deaminase (ADA) deficiency SCID.

- Characteristic radiological changes can help in early suspicion and diagnosis of ADA deficiency SCID so that definitive treatment can be instituted.

(black arrow, figure 1), flattening of lower end of the right scapula (white arrow, figure 1) and a spur at the inferior-lateral angle of the left scapula (white arrow head, figure 1). These characteristic radiological changes (ie, cupping at ends of ribs, flattening of the lower end of the scapula and a spur at the inferolateral angle of the scapula) are seen in severe combined immunodeficiency (SCID) due to an underlying adenosine deaminase (ADA) deficiency and provide an important diagnostic clue. ${ }^{1} \mathrm{He}$ had undetectable levels of immunoglobulins (IgG $<202 \mathrm{mg} / \mathrm{dL}, \operatorname{IgA}<17 \mathrm{mg} / \mathrm{dL}$ and IgM $<25 \mathrm{mg} / \mathrm{dL}$ ). ADA activity was $0.1 \mathrm{nmol} /$ hour/ $\mathrm{mg}$ (normal range $26.4 \pm 10$ ), thus suggesting a diagnosis of SCID due to an underlying ADA deficiency.

Contributors Both the authors have contributed to the preparation and editing of this manuscript.

Competing interests None declared.

Patient consent Obtained.

Provenance and peer review Not commissioned; externally peer reviewed.

(c) BMJ Publishing Group Ltd (unless otherwise stated in the text of the article) 2017. All rights reserved. No commercial use is permitted unless otherwise expressly granted.

\section{REFERENCE}

1 Manson D, Diamond L, Oudjhane K, et al. Characteristic scapular and rib changes on chest radiographs of children with ADA-deficiency SCIDS in the first year of life. Pediatr Radiol 2013;43:589-92.

Copyright 2017 BMJ Publishing Group. All rights reserved. For permission to reuse any of this content visit http://group.bmj.com/group/rights-licensing/permissions.

BMJ Case Report Fellows may re-use this article for personal use and teaching without any further permission.

Become a Fellow of BMJ Case Reports today and you can:

- Submit as many cases as you like

- Enjoy fast sympathetic peer review and rapid publication of accepted articles

- Access all the published articles

- Re-use any of the published material for personal use and teaching without further permission

For information on Institutional Fellowships contact consortiasales@bmjgroup.com

Visit casereports.bmj.com for more articles like this and to become a Fellow 